\title{
Blasts 0.01 Percent or More of Bone Marrow Nucleated Cells
}

National Cancer Institute

\section{Source}

National Cancer Institute. Blasts 0.01 Percent or More of Bone Marrow Nucleated Cells. NCI Thesaurus. Code C157653.

A semi-quantitative microscopic finding indicating that at least 0.01 percent of the nucleated cells in a bone marrow sample are immature mononuclear cells. 